\title{
The genus Dolichandrone (Fenzl.) Seem. (Bignoniaceae) in Thailand
}

\author{
WEEREESA BOONTHASAK ${ }^{\boldsymbol{\nu}}$, CHATCHAI NGERNSAENGSARUAY ${ }^{\boldsymbol{v}}$ \\ Department of Botany, Faculty of Science, Kasetsart University. Chatuchak, Bangkok 10900, Thailand. \\ Tel.: +662-562-5555, Fax.: +662-940-5627: `email: weereesa.bo@ku.th, ${ }^{* *}$ corresponding author: fsciccn@ku.ac.th
}

Manuscript received: 14 January 2021. Revision accepted: 1 February 2021.

\begin{abstract}
Boonthasak W, Ngernsaengsaruay C. 2021. The genus Dolichandrone (Fenzl.) Seem. (Bignoniaceae) in Thailand. Biodiversitas 22: 1120-1128. Morphological, anatomical, and palynological studies of the genus Dolichandrone (Bignoniaceae) Thailand were conducted. Three species, D. columnaris Santisuk, D. serrulata (Wall. ex DC.) Seem., and D. spathacea (L. f.) Seem. were investigated. Morphological descriptions, distributions and ecological information are provided. A key to the species based on morphological characters are leaflet margins, length of lower cylindric tube and upper campanulate tube of corolla, width of upper campanulate tube of corolla, winged seed, shape and characters of fruits, width of septum, characters and width of pseudoseptum. $D$. columnaris occurs in low-lying rice fields and marshlands only in the peninsular region. D. serrulata occurs in mixed deciduous forest and low-lying rice fields in the eastern, central and peninsular regions. D. spathacea occurs in edges of mangrove forest in the central, south-eastern and peninsular regions. A key to the species based on anatomical characters includes leaf type, number of rows of palisade cells, arrangement of axial parenchyma, and height of ray parenchyma. All pollen grains are similar and do not provide characters for identification within the genus Dolichandrone.
\end{abstract}

Keywords: Anatomy, pollen morphology, taxonomy

Abbreviations: Morphological part: AUU: Herbarium, Science Museums, University of Aarhus, Denmark; BK: Bangkok Herbarium, Department of Agriculture, Thailand; BKF: The Forest Herbarium, National Parks, Wildlife and Plant Conservation Department, Thailand; CMUB: Herbarium of Department of Biology, Chiang Mai University, Thailand; E: Herbarium, Royal Botanic Garden Edinburgh, Scotland; K: Herbarium, Royal Botanic Gardens, Kew, England; L: National Herbarium Nederland, Leiden University, The Netherlands; P: Herbier National, Muséum National d'Histoire Naturelle, Paris, France; PSU: Herbarium of Department of Biology, Prince of Songkla University, Thailand; QBG: Queen Sirikit Botanic Garden Herbarium, Thailand; Anatomical part: Ap: Axial parenchyma; Dc: Druse crystal; LoEp: Lower epidermis; Pm: Palisade mesophyll; Ps: Peltate scale; Rp: Ray parenchyma; Sm: Spongy mesophyll; St: Stomata; UpEp: Upper epidermis; V: Vessel; Xf: Xylem fiber.

\section{INTRODUCTION}

The genus Dolichandrone (Fenzl) Seem. belongs to tribe Tecomeae of the family Bignoniaceae (Fischer et al. 2004). This family consists 80 genera (POWO 2019), approximately 856 species (The Plant List 2013) distributed in tropical and subtropical regions, and only found 12 genera and 23 species in Thailand (Santisuk 1987). The genus Dolichandrone is mainly distributed in Africa, South Asia, South-East Asia, Northern Australia and Indo-Malaysia to New Caledonia consists of 11 species worldwide (POWO 2019). In Thailand, two species of Dolichandrone were reported by Santisuk (1974). In 1985 a new species of Dolichandrone was described by Thawatchai Santisuk (Santisuk 1985). Accordingly, Santisuk (1987) revised this genus and recognized three species of Dolichandrone in Thailand.

Several species of the genus Dolichandrone can be used for many aspects including, the wood of D. spathacea is used for household implements and handles for kitchen (Panshin 1932). In Borneo, the wood of this species is used for making clogs and matches, branches are used for floats of fishing nets. In Indonesia, the wood of this species is used for masks of Wayang Topeng, and used to make scabbards in Minahassa (Steenis 1977). Moreover, leaves and fruits can be used as substitute for Piper betle in chewing betel nut (Fosberg et al. 1993). In Thailand $D$. columnaris can be used for human food (Pholhiamhan et al. 2018), D. serrulata is used as ornamental plants and flowers can be used for food (Kilaso et al. 2019).

The anatomical studies of Dolichandrone conducted by Metcalfe and Chalk (1972) reported that the leaf of Dolichandrone usually with scalelike glandular hairs and the wood of D. spathacea has uniseriate homocellular ray. Gasson and Dobbins (1991) and Panshin (1932) reported that the wood of $D$. spathacea is diffuse-porous; vessels are equal in diameter; growth rings are distinct; fibers are nonseptate. The pollen grains of $D$. spathacea are large. The shape are subprolate, and tectum are reticulate (Mao et al. 2012). Moreover, lumina diameter on tectum can be used to species identification (Santanachote 1981). However, anatomical and palynological data of Thai Dolichandrone are incomprehensive.

In this research, a taxonomic treatment, a comparative study on the anatomy and palynology will be provided for completely information of Dolichandrone in Thailand. 


\section{MATERIALS AND METHODS}

\section{Morphological study}

Specimens of the genus Dolichandrone were studied from the Thai herbaria, as follows BK, BKF, CMUB, PSU, and $\mathrm{QBG}$, and digitized specimen images available on the web pages for the foreign herbaria, as follows AAU, E, K, $\mathrm{L}$ and $\mathrm{P}$. Additionally, specimens were collected from field survey in several localities of Thailand. Plant morphological characters were studied using a stereomicroscope. Measurements of the vegetative and reproductive parts were taken from dry and fresh specimens. A key to the species was constructed based on the significant morphological characters.

\section{Anatomical study}

Plant samples of three Dolichandrone species including leaves and wood were selected for anatomical study. The permanent slides of leaves were made using a paraffin technique (Johansen 1940; Kermanee 2008) and sectioned with 10-20 $\mu \mathrm{m}$ thickness by rotary microtome. The wood samples were cut in transverse, tangential and radial longitudinal sections by a sliding microtome with a thickness of 16-20 $\mu \mathrm{m}$. Then safranin and dehydration in $30 \%, 50 \%, 70 \%, 95 \%$, absolute ethanol and transferred to mixture of absolute ethanol and xylene (1:1) and finally in pure xylene.

\section{Palynological study}

Pollen grains of three Dolichandrone species were taken from dry specimens in the field survey. The samples were prepared for light microscopy (LM) and scanning electron microscopy (SEM). The method was applied from the protocol of Erdtman (1952). The pollen grains were boiled in $10 \% \mathrm{KOH}$ for at least $2 \mathrm{~min}$. The samples were washed with distilled water and dehydration in $30 \%, 50 \%$, $70 \%, 95 \%$ ethanol at least $30 \mathrm{~min}$. in each and dehydration completed with absolute ethanol. The samples were dried by critical point dried and place on stub, coated with gold particles for SEM observation. Examination, measurements, and micrographs were made using a Quanta 450 FEI. The pollen terminology follows Erdtman (1952), Punt (2007)

\section{RESULTS AND DISCUSSION}

\section{Morphological study}

Dolichandrone (Fenzl) Seem., Ann. Mag. Nat. Hist. III. 10: 31. 1862, nom. cons.; J. Bot. 1: 226. 1863; J. Bot. 8: 379. 1880; Sandwith, Taxon (4) 2: 45. 1955; Steenis, Fl. Males., Ser. 1, Spermat. 8: 141. 1977; Santisuk \& Vidal in J. F. Leroy, Fl. Cambodge, Laos \& Vietnam 22: 54. 1985; Santisuk in Smitinand \& K. Larsen, Fl. Thailand 5(1): 52. 1987. Type species: Bignonia spathacea L. f. Dolichandra sect. Dolichandrone Fenzl, Denkschr. Königl.-Baier. Bot. Ges. Regensburg 3: 265. 1841.

Deciduous or evergreen trees. Leaves imparipinnate, decussate, 3-11 leaflets, opposite, leaflets lanceolate or ovate, apex acuminate or caudate, base oblique or cuneate, margin entire, serrate or dentate, chartaceous, lower surface with domatia in the axil of base of lateral veins and midrib. Inflorescences raceme, 3-15 flowers, terminal or ramiflorous, nocturnal and fall in the early morning. Calyx green, closed in bud, later spathaceous, arcuate, beaked, usually with densely dark brown glands on posterior end. Corolla white, basal tube slender cylindric, upper tube campanulate with 5 crisped lobes, corolla lobes with scattered yellow glands outside. Stamens didynamous, staminode present. Disc annular, Ovary superior, parietal placentation, carpel 2, ovule numerous. Fruits loculicidal capsule, linear and twisted or subcylindrical and slightly arcuate, septum cruciform, pseudoseptum undulating, thick and corky or flat and hard. Seeds numerous, with lateral hyaline or thick winged.

\section{Key to the species}

\section{(based on morphological characters)}

1. Leaflet margins serrate or dentate; lower cylindric tube as long as upper campanulate tube or slightly longer, widest part of upper tube $8-10 \mathrm{~cm}$ wide.

\section{D. serrulata}

1. Leaflet margins entire; lower cylindric tube longer than upper campanulate tube, widest part of upper tube 4-6.5 wide.

2. Fruits linear, flat and twisted; septum 2-3 mm wide; pseudoseptum thick and undulate, $1-1.2 \mathrm{~cm}$ wide; seeds with lateral hyaline winged; occurs in lowlying rice fields and marshlands in the Peninsular.

1. D. columnaris

2. Fruits subcylindrical, straight to slightly arcuate; septum $0.8-1 \mathrm{~cm}$ wide; pseudoseptum thin and hard, not undulate, $1.5-1.8 \mathrm{~cm}$ wide; seeds with thick winged; occurs in edges of mangrove forest in the Central, South-Eastern and Peninsular.

3. D. spathacea

\section{Dolichandrone columnaris Santisuk}

Dolichandrone columnaris Santisuk, Bull. Mus. Natl. Hist. Nat. Paris, ser. 4, sect. B, Adansonia 71: 97. 1985; Santisuk \& Vidal in J. F. Leroy, Fl. Cambodge, Laos \& Vietnam 22: 56. P1. 8, 4-8. 1985; Santisuk in Smitinand \& K. Larsen, Fl. Thailand 5(1): 54. 1987. Type: Thailand, Satun, Rattaphum-Hat Yai route, T. Santisuk 6629, holotype BKF [BKF080043]

Evergreen trees 7-25 m high. Bark scaly, greyish-brown or grey. Leaves: petioles 4-7 cm long, rachis 3-8 cm long, 3-9 leaflets, opposite, lanceolate or ovate, $6-12$ by $3-5 \mathrm{~cm}$, apex acuminate or caudate, base oblique, except terminal leaflet cuneate, margin entire, chartaceous, 4-6 lateral veins on each side, veinlets reticulate, lower surface with domatia in the axil of base of lateral veins and midrib, petiolule 1$2.5 \mathrm{~cm}$ long. Inflorescences short raceme, terminal, 3-5 flowers, peduncle short, rachis $0.5-2.5 \mathrm{~cm}$ long, pedicel 1.5-2 cm long. Calyx green, closed in bud, later spathaceous, $2.3-4.5$ by $1.5-2.5 \mathrm{~cm}$, arcuate, beaked, usually with densely dark brown glands on posterior end. Corolla white, bilabiate, basal tube slender cylindric, 9.5$10.5 \mathrm{~cm}$ by $5-8 \mathrm{~mm}$, upper tube campanulate, $4.5-7.5$ by $4-$ 
$6 \mathrm{~cm}$, lobes crisped, with scattered yellow glands outside. Stamens 4, longer pair 2.5-3 cm long, shorter pair 1.5-2.5 $\mathrm{cm}$ long, anther 3-5 mm long, divaricate, staminode 1, 4-7 $\mathrm{mm}$ long. Pistil 9.5-12.7 cm long, ovary linear, 5-6 mm long, style pale green, 9-12 cm long, stigma 2 lobes. Fruits linear, 26-70 by $1.2-2 \mathrm{~cm}$, flatted and twisted, dry fruit brown, septum 2-3 mm wide, pseudoseptum 1-1.2 cm wide, wavy, thick and corky. Seeds flat, rectangular, 2-3 $\mathrm{cm}$ by $5-7 \mathrm{~mm}$ with lateral hyaline winged. (Figure 1)

Thailand. SOUTH-EASTERN: Rayong [Klaeng, Chak Phong, Ban Phlong Sawai, 8 June 2006, K. Kertsawang 598 (QBG!)]; PENINSULAR: Trang [Mueang Trang, Ban Bang Rak, 20 Apr. 2004, P. Pattarakulpisutti 268 (PSU!); 14 June 1987, T. Santisuk 6634 (BKF!)]; Satun [Khuan Don, Thale Ban National Park, 12 Mar. 2004, S. Gardner \& P. Sidisunthorn ST0208 (BKF!, QBG!); La-ngu, 14 June 1987, T. Santisuk 6632 (BKF!); ibid., T. Santisuk 6633 (BKF!)]; Songkhla [Rattaphum, 17 Feb. 2003, U. Upho UBON447 (QBG!); Ranot, 23 Nov. 2017, W. Boonthasak, C. Ngernsaengsaruay, N. Meeprom \& P. Wessapak 1, 2, 3, 4 (BK!, BKF!, QBG!); Hat Yai, 30 May 1958, J. F. Maxwell 85-551, (BKF!); Ranot, 12 Aug. 2009, P. Sutthinon s.n. (PSU!)]

Distribution. Vietnam, Cambodia

Ecology. Low-lying rice fields and marshlands, near sea level; flowering and fruiting almost throughout the year.

Vernacular name. Khae thung (แคทุ่ง), Khae na (แคนา), Khae yot dam (แคยอดดำ) (Peninsular)

\section{Dolichandrone serrulate (Wall. ex DC.) Seem.}

Dolichandrone serrulata (Wall. ex DC.) Seem., J. Bot. 8: 383. 1870; Santisuk in Santisuk, Thai Forest Bull., Bot. 8: 18. 1974; Santisuk in Smitinand \& K. Larsen, Fl. Thailand 5(1): 54. 1987. Bignonia serrulata Wall. ex DC., Biblioth. Universelle Genève 17: 124. 1838. Type: Myanmar, Irrawaddy river, Paghamew, N. Wallich 6505A. holotype K [K001124069] seen on digital image. Spathodea serrulata Wall. ex DC. DC., Prodr. 9: 206. 1845. Stereospermum serrulatum DC. Biblioth. Universelle Genève 17: 124. 1838; Kurz, Forest Fl. Burma 2: 230.1877 .

Deciduous trees, 7-20 m high, Bark scaly, greyishbrown or brown. Leaves: petioles 3-9 cm long, rachis 5-17 cm long, 7-11 leaflets, opposite, ovate or lanceolate, 6-11 by $3-5 \mathrm{~cm}$, apex acuminate or caudate, base oblique except terminal leaflet cuneate, margin serrate or dentate, chartaceous, 4-8 lateral veins on each side, lower surface with domatia in the axil of base of lateral veins and midrib, petiolule $0.6-3.5 \mathrm{~cm}$ long. Inflorescences raceme or short raceme, terminal or ramiflorous, 3-15 flowers, peduncle 3$8 \mathrm{~cm}$ long, rachis $0.5-13.5 \mathrm{~cm}$ long, Calyx green, closed in bud, later spathaceous, $3-6$ by $2-2.8 \mathrm{~cm}$, arcuate, beaked, usually with densely dark brown glands on posterior end. Corolla white, bilabiate, basal tube slender cylindric, pale green, $8-10 \mathrm{~cm}$ by $5-9 \mathrm{~mm}$, upper tube campanulate, white, $8-10$ by $8-10 \mathrm{~cm}$, lobes crisped, with scattered yellow glands outside. Stamens 4, longer pair $3.2-4.5 \mathrm{~cm}$ long, shorter pair 2.5-3.5 cm long, anther 5-7 mm long, divaricate, staminode 1, 0.5-1.2 cm long. Pistil $11-13 \mathrm{~cm}$ long, ovary linear, 1.3-2 cm long, style pale green, 10-12 cm long, stigma 2 lobes. Fruits linear, $50-120$ by $1.2-1.7$ $\mathrm{cm}$, flatted and twisted, dry fruit brown, septum 3-4 mm wide, pseudoseptum 1-1.2 cm wide, wavy, thick and corky. Seeds flat, rectangular, $3-3.7$ by $0.5-0.7 \mathrm{~cm}$ with lateral hyaline winged. (Figure 1)

Thailand. NORTHERN: Chiang Mai [Doi Noi, Mae Ping, 28 Apr. 1921, A. F. G. Kerr 5271 (BKF!)]; Lamphun [Tha Sop Chai, Mae Tha, 21 Mar. 2010, N. Romkham 245 (QBG!)]; Lampang [ Ngao, 17 May 1997, Amnat 17 (BKF!); ibid., 13 May 1954, P. Bhanthu 2 (BKF!); Doi Pha Khok Hin Fu Volcano, Mae Tha, 12 Mar. 2012, K. Jatupol, C. Maknoi \& K. Warintorn 721 (QBG!); Ngao 13 May 1954, Sukrit s.n. (BKF!); ibid., 14 May 1954, Vichai 4 (BKF!); 23 Apr. 1923, Winit 845 (BKF!)]; Tak [Wang Chao, 25 Aug. 1996, BGO. Staff. 233 (QBG!); Mae SotUmphang Road., W. Nanakorn et al. 9807, 9808 (QBG!)]; Kamphaeng Phet [21 Apr. 2004, R. Pooma, K. Phattarahirankanok, S. Sirimongkol \& M. Poopath 3842 (BKF!)]; Phichit [Mueang Phichit, 25 Mar. 1922, A. F. G. Kerr 5445 (BK!)]; NORTH-EASTERN: Loei [Wang Saphung, 25 July 1946, D. Nakkarn 130 (BKF!)]; Sakon Nakhon [ 28 June 1932, M. C. Lakshnakara 1077 (BK!); Waritchaphum, 14 Mar. 2006, W. McClatchey \& P. Mokkamul WCM4017 (BKF!)]; Kalasin [Yang Talat, 23 Mar. 2007, K. Wangwasit, M. Norsaengsri \& C. Lakoet 070323-27 (BKF!, QBG!); 6 June 1990, M. Widmer 0015 (BKF!)]; Maha Sarakham [Ban Muang Yai, Kosum Phisai, 2 May 2001, M. Norsaengsri, W. Boonchai \& W. Nanakorn 1420 (QBG!)]; Khon Kaen [Phon, 23 Apr. 2008, M. Norsaengsri 3721 (QBG!)]; EASTERN: Chaiyaphum [June 1984, T. Santisuk s.n. (BKF!); Nakhon Ratchasima [Khao Yai National Park, 28 May 1997, BGO. Staff. 9180 (QBG!); Ban Thong Lang Yai, Bua Yai, 18 Mar. 2009, M. Norsaengsri 5126 (QBG!); Ban Lam, Khong, 20 Mar. 2009, M. Norsaengsri 5215 (QBG!); 16 Mar. 1958, T. Smitinand 4465 (BKF!); 16 Mar. 1958, Th. Sørensen, K. Larsen \& B. Hansen 2167 (BKF!)]; CENTRAL: Saraburi [23 Apr. 2004, R. Pooma, K. Phattarahirankanok, S. Sirimongkol \& M. Poopath 3913 (BKF!)]; Bangkok [Department of Agriculture, Kasetsart University (cultivated), 10 Apr. 2017, W. Boonthasak, K. Ditprim \&

S. S-ard 5 (BK!, BKF!, QBG!); Faculty of Education, Kasetsart University (cultivated), 16 Mar. 2016, $W$. Boonthasak, K. Ditprim \& T. Iamarrom 6 (BK!, BKF!)

Distribution. Bangladesh, Myanmar, Laos, Vietnam

Ecology. Mixed deciduous forest and low-lying rice fields, 0-300 m a.m.s.1.; flowering and fruiting in March to June.

Vernacular name. Khae kettawa (แคเก็ตตว) (Chiang Mai), Khae Khao (แคขาว) (Chiang Mai), Khae tui (แคตุ้ย) (Northern), Khae sai (แคทราย) (Nakhon Ratchasima), Khae na (แคนา) (Central), Khae nae (แคแน), Khae pa (แคป่า) (Lampang, Loei),

Khae foi (แคฝอย), Khae fa (แคฝา) (Northern), Khae phu ho (แคพู่อ) (Lampang), Khae yao (แคยาว) (Prachin Buri), Khae yui ho (แคหยุยฮ่อ), Khae haen hae (แคแหนแห้) (Northern), Khae ao (แคอาว) (Prachin Buri) 
Dolichandrone spathacea (L. f.) Seem.

Dolichandrone spathacea (L. f.) Seem., Fl. Kais. Wilh. Land 123. 1889; Santisuk, Thai Forest Bull., Bot. 8: 18. 1974; Steenis, Fl. Males., Ser. 1, Spermat. 8: 142. fig. 15-16. 1977; Santisuk \& Vidal in J. F. Leroy, Fl. Cambodge, Laos \& Vietnam 22: 57. P1. 8, 9-11. 1985; Santisuk in Smitinand \& K. Larsen. Fl. Thailand 5(1): 56. 1987. Bignonia spathacea L. f., Suppl. Pl. 283. 1781. Bignonia longissima Lour., Fl. Cochinch. 2: 380. 1790, non Jacq. 1760. Dolichandrone longissima (Lour.) K. Schum., Nat. Pflanzenfam. 4. 3b: 240. 1894. Spathodea rheedii Spreng., Syst. Veg. 2: 835. 1825; Kurz, Forest Fl. Burma 2: 234. 1877. Type: India, Calcutta Botanic Garden, s. coll. 6516 holotype K [K000639629] seen on digital image. Dolichandrone rheedii (Spreng.) Seem., J. Bot. 8: 380. 1870; Clarke, Fl. Brit. India 4: 379. 1884.

Evergreen trees, 4-10 m high. Bark smooth, brown or greyish-brown, Leaves: petioles 3-11 cm long, rachis 4-16 cm long, 3-9 leaflets, opposite, lanceolate or ovate, 6-16.5 by $2-6 \mathrm{~cm}$, apex caudate or acuminate, base oblique except terminal leaflet cuneate, margin entire, subcoriaceous, 5-8 lateral veins on each side, lower surface with domatia in the axil of base of lateral veins and midrib, petiolule $0.8-3$ $\mathrm{cm}$ long, Inflorescences short raceme, terminal, rachis 1$2.5 \mathrm{~cm}$ long, 3-6 flowers, peduncle 1-1.5 cm long. Calyx green, closed in bud, later spathaceous, $3-6$ by $1.8-2.5 \mathrm{~cm}$, arcuate, beaked, usually with densely dark brown glands on posterior end. Corolla white, bilabiate, basal tube slender cylindric, pale green, $9-12 \mathrm{~cm}$ by $5-9 \mathrm{~mm}$, upper tube campanulate, white, $4-6$ by $4.5-6.5 \mathrm{~cm}$, lobes crisped, with scattered yellow glands outside. Stamens 4, longer pair 2$2.7 \mathrm{~cm}$ long, shorter pair 1.5-2.2 cm long, anther 4-6 mm long, divaricate, staminode 1, 5-6 mm long. Pistil 3-11 cm long, ovary cylindric, $1-1.3 \mathrm{~cm}$ long, style pale green, 3-11 cm long, stigma 2 lobes. Fruits terete, straight to slightly arcuate, $36-45$ by $2-3 \mathrm{~cm}$, dry fruit grey, septum undulate, $0.8-1 \mathrm{~cm}$ wide, pseudoseptum not undulate, $1.5-1.8 \mathrm{~cm}$ wide, thin and hard. Seeds flat, rectangular, $1.2-1.8 \mathrm{~cm}$ by $5-8 \mathrm{~cm}$ with thick winged. (Figure 1)

Thailand. CENTRAL: Bangkok [Department of Agriculture, Easy Contact Center (cultivated) 11 Apr.
2017, W. Boonthasak \& S. S-ard 9, (BK!, BKF!); 1 Sept. 1997, C. Niyomdham 5129 (BKF!); Samut Prakan [Phra Pradaeng, Bangnamphueng Flaoting Market, 19 Feb. 2017, W. Boonthasak \& W. Boonlum 10 (BK!, BKF!, QBG!)]; Samut Sakhon [18 May 1980, K. Iwatsuki s.n. (BKF!); SOUTH-EASTERN: Trat, Ko Chang, 7 Aug. 1955, Bunnak 472 (BKF!); PENINSULAR: Ranong [Suk Samran, 8 June 2016, W. Boonthasak \& K. Ditprim 8 (BK!, BKF!, QBG!)]; Surat Thani [14 June 1984, T. Santisuk s.n. (BKF!)]; Phattalung [23 Aug. 2011, U. Chanthorn 1 (PSU!)]; Satun [La-ngu, Tarutao National Park, 20 May 2005, S. Gardner, P. Sidisunthorn \& T. Utteridge ST1843 (BKF!); Khuan Don, 1992, A. F. G. Kerr 13776 (BKF!)]

Distribution. India, Bangladesh, Sri Lanka, Andaman Is., Nicobar Is., Myanmar, Southeast China, Hainan, IndoChina, Malaysia, Borneo, Indonesia (Java, Sumatra, Sulawesi, Moluccas, Lesser Sunda Is.), Philippines, Papua New Guinea, Bismarck Archipelago, New Caledonia, Queensland.

Ecology. Edges of mangrove forest, near sea level; flowering and fruiting in March to June.

Vernacular name. Khae thale (แคทะเล) (Trat), Khae nam (แคน้ำ) (Central)

Santisuk (1974, 1987) used characters as follows: leaflet margins, length of lower cylindric tube and upper campanulate tube of corolla, pseudoseptum, and winged seed for identification of these three species. In this research we use information including width of upper campanulate tube of corolla, shape and characters of fruits, width of septum and pseudoseptum, distribution, and ecology for species identification. (Table 1)

After the specimens examined in the herbaria, we found that three species of Dolichandrone are often misidentified because they are similar in characters. Leaves and flowers of D. columnaris and D. spathacea are similar but fruits, seeds, and, natural habitats are different. In the same way, fruits, seeds, and natural habitats of $D$. columnaris and $D$. serrulata are similar but leaf margins, flower size, and distribution are different. Therefore, we can use these significant characters for species identification.

Table 1. The comparison of some morphological characters of the genus Dolichandrone in Thailand

\begin{tabular}{llll}
\hline Characters & D. columnaris & D. serrulata & D. spathacea \\
\hline Leaf margins & Entire & Serrate or dentate & Entire \\
Width of upper campanulate tube of corolla & $4-6 \mathrm{~cm}$ & $8-10 \mathrm{~cm}$ & $4.5-6.5 \mathrm{~cm}$ \\
Length of upper campanulate tube of corolla & $4.5-7.5 \mathrm{~cm}$ & $8-10 \mathrm{~cm}$ & $4-6 \mathrm{~cm}$ \\
Length of lower cylindric tube of corolla & $9.5-10.5 \mathrm{~cm}$ & $8-10 \mathrm{~cm}$ & $9-12 \mathrm{~cm}$ \\
Shape, characters and length of fruits & Linear, flat and twisted, & Linear, flat and twisted, & Terete, straight to slightly \\
& $36-70 \mathrm{~cm}$ long & $50-120 \mathrm{~cm}$ long & $36-45 \mathrm{~cm}$ long \\
Width of pseudoseptum & $1-1.2 \mathrm{~cm}$ & $1-1.2 \mathrm{~cm}$ & $1.5-1.8 \mathrm{~cm}$ \\
Width of septum & $2-3 \mathrm{~mm}$ & $3-4 \mathrm{~mm}$ & $0.8-1 \mathrm{~cm}$ \\
Characters of pseudoseptum & Undulate, thick and corky & Undulate, thick and corky & Not undulate, thin and hard \\
Seeds & With lateral hyaline winged & With lateral hyaline winged & With lateral thick winged
\end{tabular}




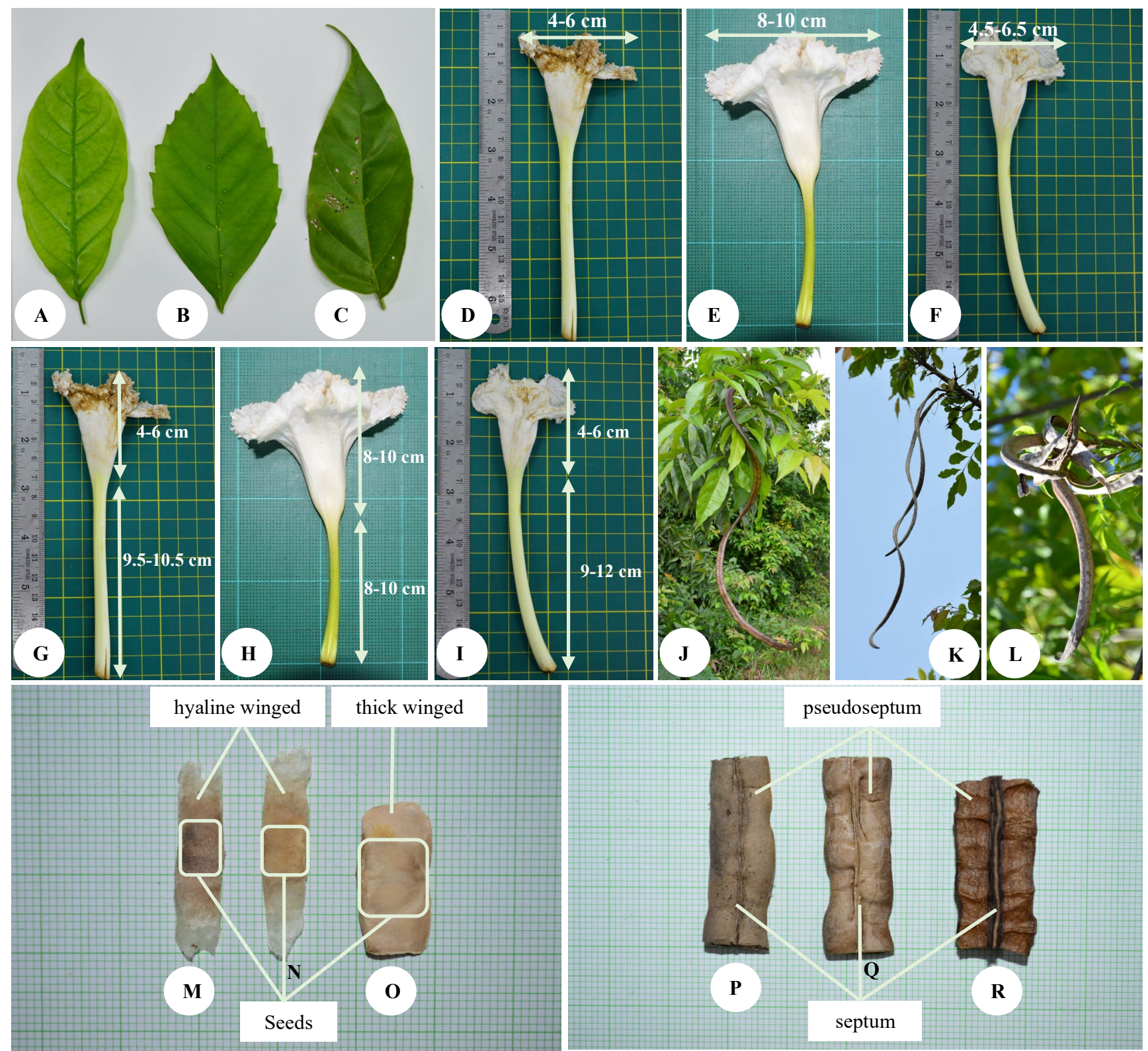

Figure 1. The differences among 3 Dolichandrone species: A-C. leaflets; D-I. flowers; J-L. fruits; M-O. seeds with lateral hyaline winged and thick winged; P-R. septum and pseudoseptum; D. columnaris (A, D, G, J, M, P); D. serrulata (B, E, H, K, N, Q); D. spathacea $(\mathrm{C}, \mathrm{F}, \mathrm{I}, \mathrm{L}, \mathrm{O}, \mathrm{R})$

\section{Anatomical study}

\section{Dolichandrone columnaris Santisuk}

Leaves are unifacial, epidermis is a single layer, epidermal cells on the upper side are larger than the lower side. Stomata are anomocytic, typical and confined to the lower surface, peltate scale present on both surfaces. Mesophyll with 2 rows of palisade cells on both sides. Druse crystals present in parenchyma between palisade mesophyll. (Table 2; Figure 2A, D; Figure 3A)

Wood diffuse-porous. Vessels are single or group 2-7 cells, mostly $30-70 \mu \mathrm{m}$ in diameter and 173-490 $\mu \mathrm{m}$ in length. Axial parenchyma are banded. Rays are uniseriate heterocellular with procumbent 6-14 cells long sometimes 2-5 or 15-20 cells long, 1 row of upright marginal cells, sometimes biseriate. Fibers are septate. (Table 2; Figure $4 \mathrm{~A}, \mathrm{D}, \mathrm{G})$
Dolichandrone serrulata (Wall. ex DC.) Seem.

Leaves are bifacial, epidermis is a single layer, epidermal cells on the upper side are larger than the lower side. Stomata are anomocytic, typical and confined to the lower surface, peltate scale present on both surfaces. Mesophyll with 1 row of palisade cells on the upper side and 3 rows of spongy cells on the lower side. Druse crystals present in spongy mesophyll. (Table 2; Figure 2B, E; Figure 3B)

Wood diffuse-porous. Vessels are single or group 2-5 cells, mostly 40-70 $\mu \mathrm{m}$ in diameter and 165-425 $\mu \mathrm{m}$ in length. Axial parenchyma are confluent. Rays are uniseriate heterocellular with procumbent 3-45 cells long sometimes up to 60 cells long, 1 row of upright marginal cells, sometimes biseriate. Fibers are septate. (Table 2; Figure 4B, E, H) 
Dolichandrone spathacea (L. f.) Seem.

Leaves are bifacial, epidermis is a single layer, epidermal cells on the upper side are larger than the lower side. Stomata are anomocytic, typical and confined to the lower surface, peltate scale present on both surfaces. Mesophyll with 2 rows of palisade cells on the upper side and 2 rows of spongy cells on the lower side. Druse crystals present in spongy mesophyll. (Table 2; Figure 2C, F; Figure 3C)

Wood diffuse-porous. Vessels are single or group 2-4 cells, mostly $50-90 \mu \mathrm{m}$ in diameter and $180-430 \mu \mathrm{m}$ in length. Axial parenchyma are banded. Rays are uniseriate heterocellular with procumbent 4-19 cells long sometimes 2 cells, 1 row of upright marginal cells, sometimes biseriate. Fibers are septate. (Table 2; Figure 4C, F, I)

The result of anatomical characters showed that leaves of 3 Dolichandrone species without branched multicellular hairs on epidermis, and without tracheid-like vessel in wood inconsistent with Metcalfe and Chalk (1972). However, the wood of three Dolichandrone species has uniseriate heterocellular rays, and axial parenchyma are confluent and banded consistent with Metcalfe and Chalk (1972) and Gasson and Dobbins (1991)

Some anatomical characters of Dolichandrone including leaf type, number of row of palisade cells, arrangement of axial parenchyma, and height of ray parenchyma can be supporting the species identification shown in a key to the species below.

\section{Key to the species}

\section{(based on anatomical characters)}

1. Unifacial leaf

1. Bifacial leaf

\section{D. columnaris}

2. Mesophyll with 1 row of palisade cells, wood with confluent axial parenchyma, ray parenchyma 3-60 cells high

2. D. serrulata

2. Mesophyll with 2 rows of palisade cells, wood with banded axial parenchyma, ray parenchyma 2-19 cells high

3. D. Spathacea

Table 2. The comparison of some anatomical characters of the genus Dolichandrone in Thailand

\begin{tabular}{llll}
\hline Characters & D. columnaris & D. serrulata & D. spathacea \\
\hline Leaf type & Unifacial leaf & Bifacial leaf & Bifacial leaf \\
Number of rows of palisade cells & 2 & 1 & 2 \\
Vessel Arrangement & Diffuse porous & Diffuse porous & Diffuse porous \\
Vessel diameter $(\mu \mathrm{m})$ & $30-70$ & $40-70$ & $50-90$ \\
Vessel length $(\mu \mathrm{m})$ & $173-490$ & $165-425$ & $180-430$ \\
Axial parenchyma & Banded & Confluent & Banded \\
Ray parenchyma & Uniserriate heterocellular & Uniserriate heterocellular & Uniserriate heterocellular \\
Ray height $($ cells) & $(2-) 6-14(-20)$ & $3-45(-60)$ & $(2-) 4-19$ \\
Ray width $($ cells) & $1(-2)$ & $1(-2)$ & $1(-2)$ \\
Fibers & Septate & Septate & Septate \\
\hline
\end{tabular}
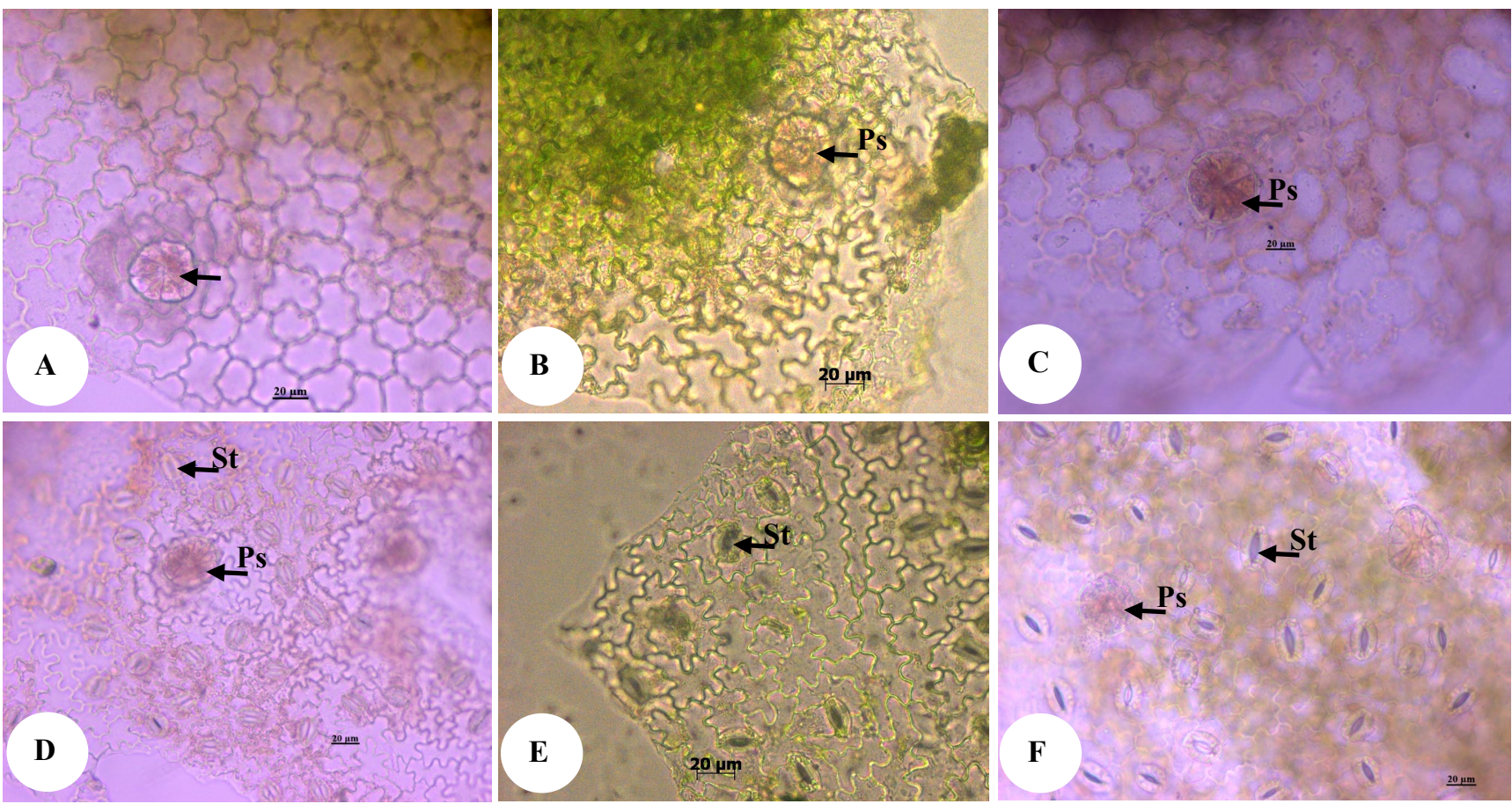

Figure 2. Epidermal cells of leaves of 3 Dolichandrone species: A-C. upper epidermis; D-F. lower epidermis; D. columnaris (A, D); D. serrulata (B, E); D. spathacea (C, F) [Ps: Peltate scale, St: Stomata] 

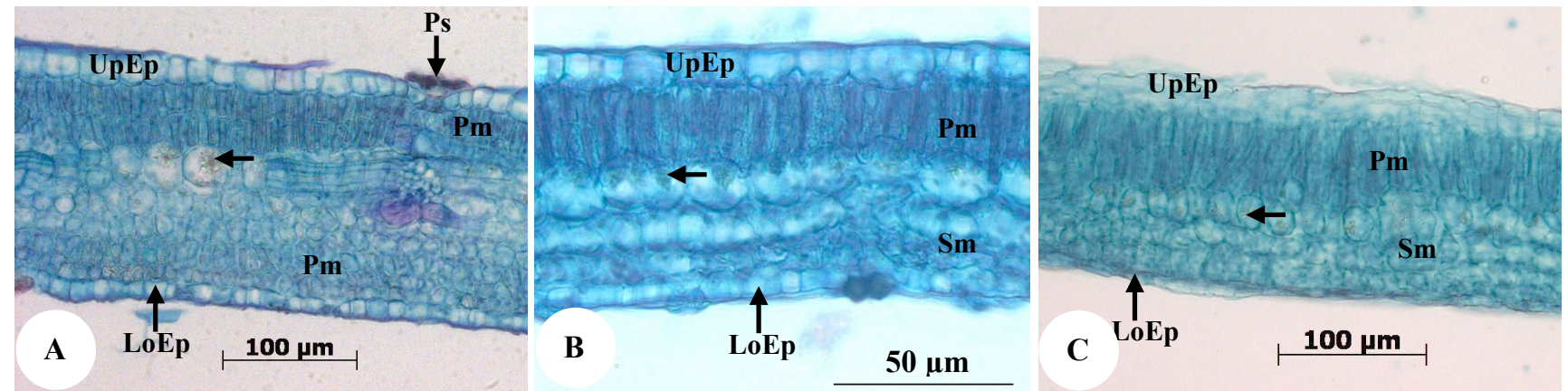

Figure 3. Leaf in transverse section of 3 Dolichandrone species: A. D. columnaris; B. D. serrulata; C. D. spathacea [Dc: Druse crystal, LoEp: Lower epidermis, Pm: Palisade mesophyll, Ps: Peltate scale, Sm: Spongy mesophyll, UpEp: Upper epidermis]
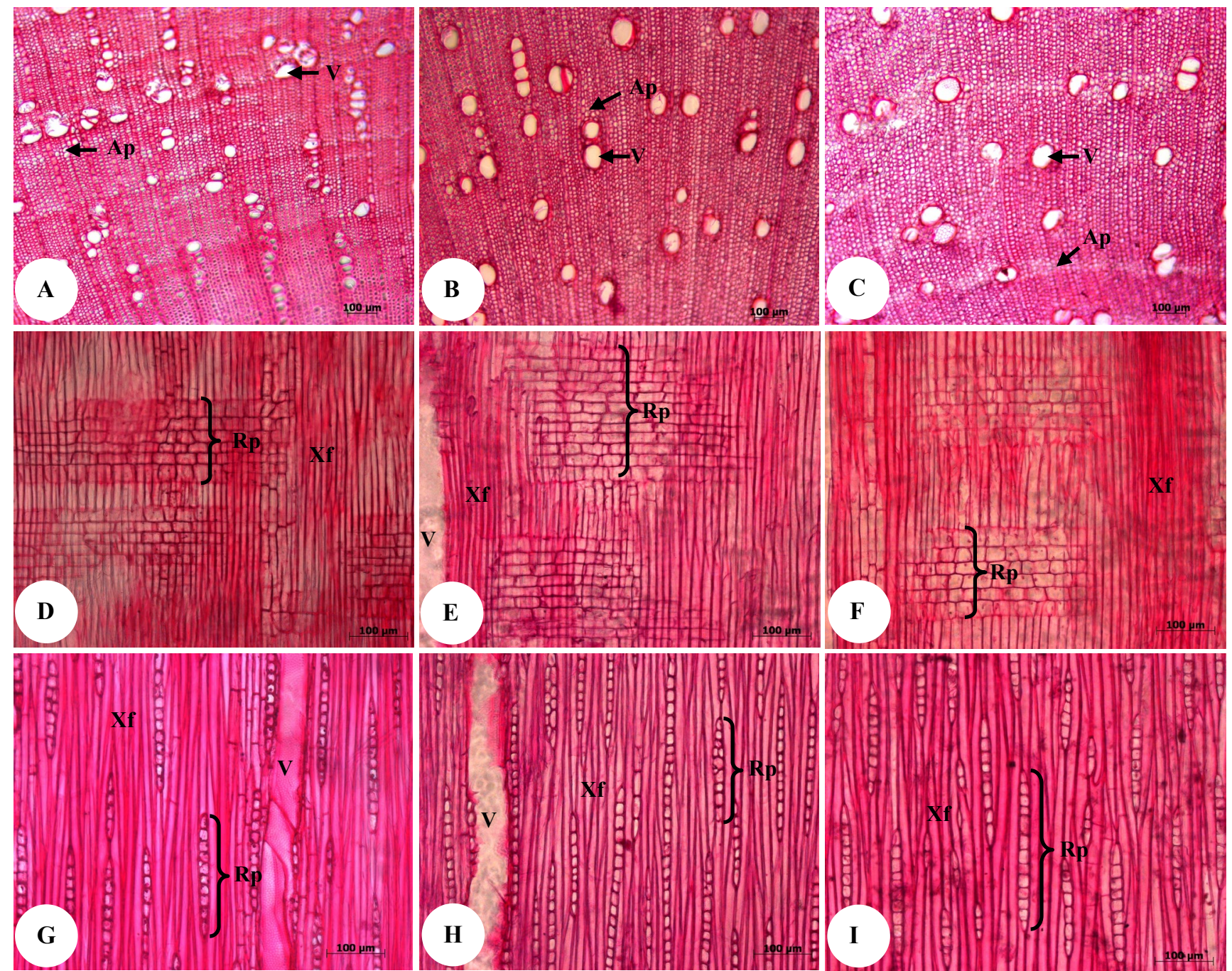

Figure 4. Wood anatomy of 3 Dolichandrone species: A-C. transverse section, D-F. radial longitudinal section, G-I. tangential longitudinal section; D. columnaris (A, D, G), D. serrulata (B, E, H), D. spathacea (C, F, I); [Ap: Axial parenchyma, Rp: Ray parenchyma, V: Vessel, Xf: Xylem fibre] 


\section{Palynological study}

Dolichandrone columnaris Santisuk

Pollen grains are monad, isopolar, spheroidal to prolatespheroidal, polar axis with $45-58 \mu \mathrm{m}$, equatorial axis with 49-57 $\mu \mathrm{m}$, tricolpate, the exine sculpture is microreticulate (lumina smaller than $1 \mu \mathrm{m}$ ) and fine reticulate (lumina between 1-2 $\mu \mathrm{m}$ ) and medium reticulate (lumina between 2-3 $\mu \mathrm{m}$ ) (Figure 5A, D)

\section{Dolichandrone serrulata (Wall. ex DC.) Seem.}

Pollen grains are monad, isopolar, spheroidal to prolatespheroidal, polar axis with 45-65 $\mu \mathrm{m}$, equatorial axis with $35-45 \mu \mathrm{m}$, tricolpate, the exine sculpture is microreticulate and fine reticulate (Figure $5 \mathrm{~B}, \mathrm{E}$ )

Dolichandrone spathacea (L. f.) Seem.

Pollen grains are monad, isopolar, spheroidal to prolatespheroidal, polar axis with $35-45 \mu \mathrm{m}$, equatorial axis with
$30-40 \mu \mathrm{m}$, tricolpate, the exine sculpture is microreticulate and fine reticulate (Figure $5 \mathrm{C}, \mathrm{F}$ )

Santanachote (1981) reported that size of lumina on pollen exine of Thai Dolichandrone can be used for the species identification, but in this research, we found that lumina diameter on exine sculpture of 3 Dolichandrone species are similar, so this character cannot be used for identification within the genus.

The pollen grains of 3 species are large grain, spheroidal to prolate-spheroidal shape. The pollen aperture is tricolpate and the pollen exine sculpture is reticulate consistent with Erdtman (1952) and Mao et al. (2012). However, the pollen morphology of 3 Dolichandrone are similar and do not provide characters for identification within the genus. (Table 3)

Table 3. The comparison of some pollen morphological characters of the genus Dolichandrone in Thailand

\begin{tabular}{llll}
\hline Characters & D. columnaris & D. serrulata & D. spathacea \\
\hline Polar axis & $45-58 \mu \mathrm{m}$ & $45-65 \mu \mathrm{m}$ & $35-45 \mu \mathrm{m}$ \\
Equatorial axis & $49-57 \mu \mathrm{m}$ & $35-45 \mu \mathrm{m}$ & $30-40 \mu \mathrm{m}$ \\
Shape & Spheroidal, prolate-spheroidal & Spheroidal, prolate-spheroidal & Spheroidal, prolate-spheroidal \\
Aperture & Tricolpate & Tricolpate & Tricolpate \\
Exine sculpture & Microreticulate, fine reticulate, & Microreticulate, fine reticulate & Microreticulate, fine reticulate \\
& Medium reticulate & & \\
\hline
\end{tabular}
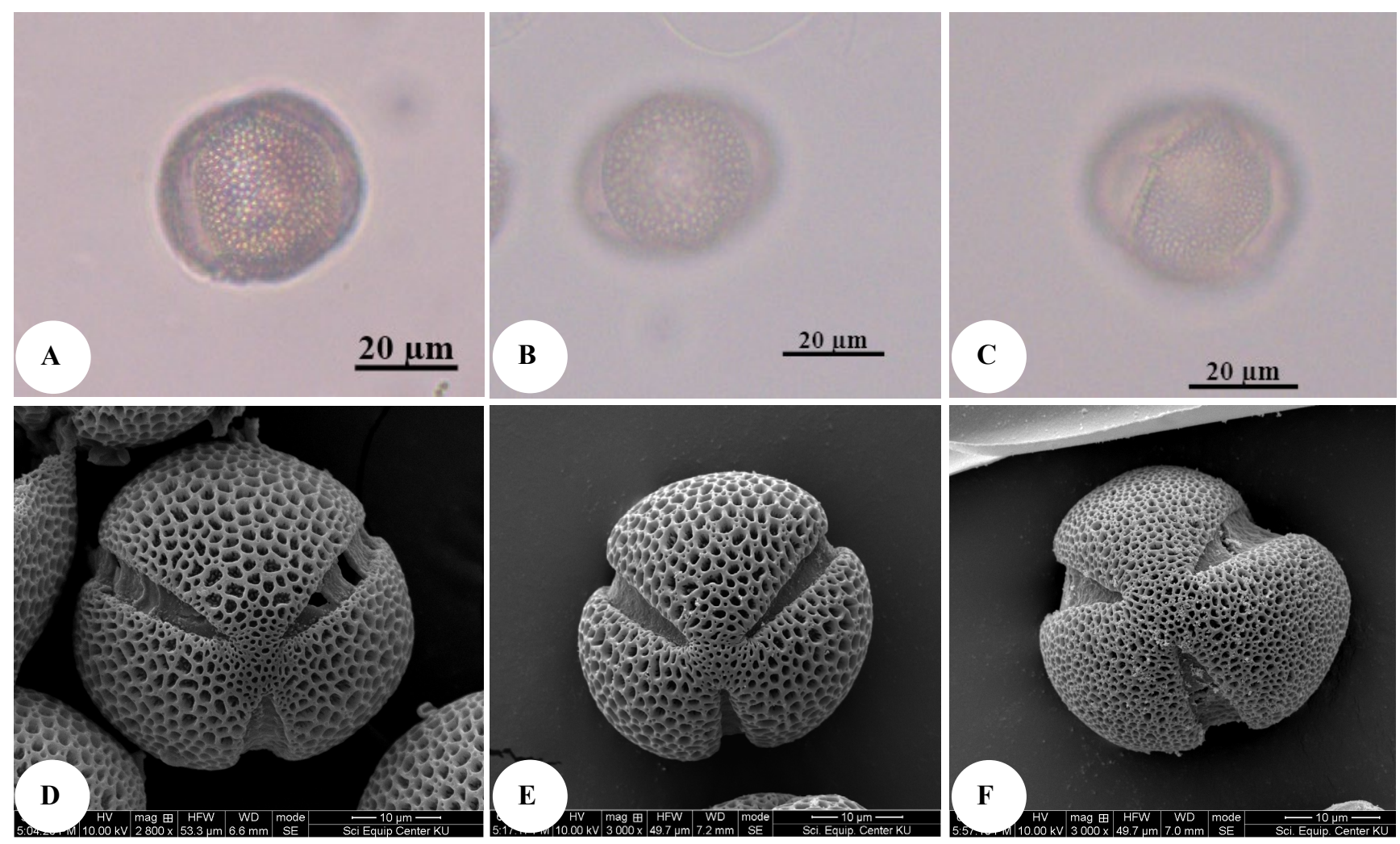

Figure 5. Pollen grains of 3 Dolichandrone species: A-C. pollen in equatorial view with LM micrographs; D-F. pollen in polar view with SEM micrographs; D. columnaris (A, D); D. serrulata (B, E); D. spathacea (C, F) 


\section{ACKNOWLEDGEMENTS}

The authors would like to thanks the curators and staff of BK, BKF, CMUB, PSU and QBG for providing access to their specimens and also staff of Scientific Equipment Center, Kasetsart University for accommodating to palynological study. This research was financially supported by the Graduate Program Scholarship (2017) from the Graduate School, Kasetsart University, and Kasetsart University Research and Development Institute, KURDI 2017 (Project No. 49.60).

\section{REFERENCES}

Erdtman G. 1952. Pollen Morphology and Taxonomy: Angiosperms (An Introduction to Palynology I). Almqvist \& Wiksells BoktryckeriAktiebolag, Uppsala, Sweden.

Fischer E, Theisen I, Lohmann LG. 2004. Bignoniaceae. In: Kadereit JW (ed.) The Families and Genera of Vascular Plants V. 7. SpringerVerlag Berlin Heidelberg, Germany.

Fosberg FR., Sachet MH, Oliver RL. 1993. Flora of Micronesia, 5: Bignoniaceae-Rubiaceae. Smithsonian Institution Press, Washington, D.C.

Gasson P, Dobbins DR. 1991. Wood anatomy of the Bignoniaceae, with a comparison of trees and lianas. Iawa Bulletin 12 (4): 389-417.

Johansen DA. 1940. Plant Microtechnique. McGraw-Hill, New York.

Kermanee P. 2008. Techniques in Plant Tissue. Kasetsart University, Bangkok. [Thai]

Kilaso M, Tigwattananont S, Bumroongsook S. 2019. Life History Characteristic and Larval-Papal Parasitoids of the Dolichandrone
Weevil, Cionus sp. (Coleoptera: Curculionidae), International Conference on Veterinary, Agriculture and Life Sciences (ICVALS), Antalya, Turkey, 26-29 October 2019.

Mao L, Batten D, Fujiki T, Li Z, Dai L, Weng C. 2012. Key to mangrove pollen and spore of Southern China: an aid to palynological interpretation of quaternary deposits in the South China Sea. Rev Palaeobot Palynol 176-177: 41-67.

Metcalfe CR, Chalk L. 1972. Anatomy of the Dicotyledons. Oxford University Press, Ely House, London, UK.

Panshin AJ. 1932. An anatomical study of the woods of the Philippine mangrove swamps. Philippine J Sci 48 (2): 194-195.

Pholhiamhan R, Saensouk S, Saensouk P. 2018. Ethnobotany of Phu Thai Ethic Group in Nakhon Phanom, Province Thailand. Walailak J Sci Technol 15 (10): 679-699.

POWO. 2019. Plants of the World Online. Facilitated by the Royal Botanic Gardens, Kew. www.plantsoftheworldonline.org/ Retrieved July 16, 2020.

Punt W, Hoen PP, Blackmore S, Nilsson S, Thomas AL. 2007. Glossary of pollen and spore terminology. Rev Palaeobot Palynol 143: 1-81.

Santanachote K. 1981. A Palynological study of the Thai Bignoniaceae. [Thesis]. Chulalongkorn University, Bangkok. (in Thai)

Santisuk T. 1974. Bignoniaceae: Dolichandrone. Thai For Bull (Botany) 8: $17-20$.

Santisuk T. 1985. A new species of Dolichandrone (Bignoniaceae) from S.E. Asia. Bulletin du Muséum National d'Histoire Naturelle Section B, Adansonia 7: 97-103.

Santisuk T. 1987. Bignoniaceae. In: Smitinand T, Larsen K (eds.). Flora of Thailand V. 5 Part 1. Chutima Press, Bangkok.

Steenis CGGJ van. 1977. Bignoniaceae. In: Steenis CGGJ van (ed.) Flora Malesiana V. 8 Part 2. Sijthoff \& Noordhoff International Publishers, the Netherlands.

TPL. 2013. The Plant List Version 1.1. Published on the Internet; http://www.theplantlist.org/1.1/browse/A/Bignoniaceae/ Dolichandrone/July 16, 2020. 